
\section{.} 3 4 5 6 27 9

\title{
New markers for qPCR detection of the dinoflagellate Alexandrium catenella in Chile
}

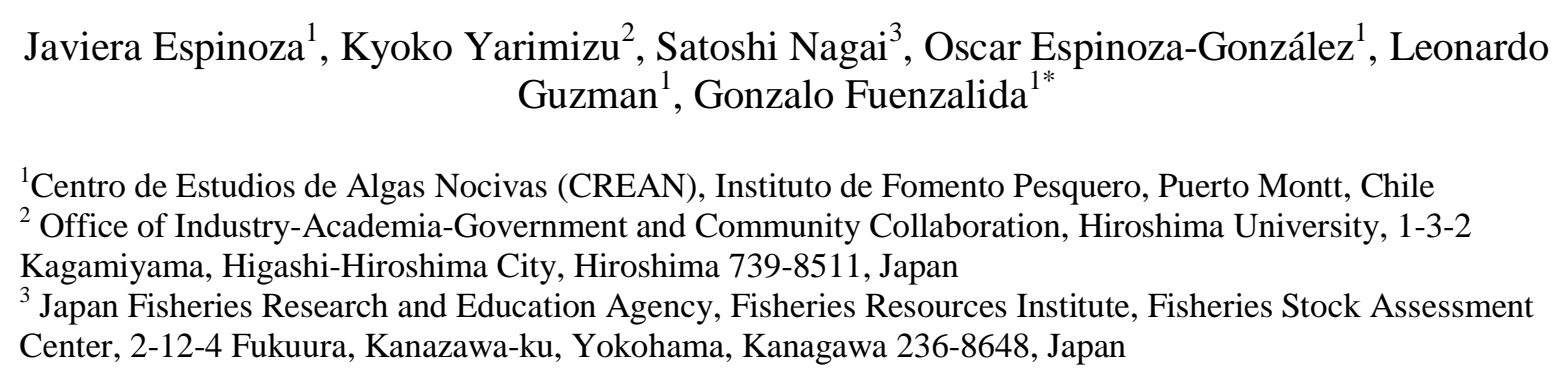

(2)

(1)

\section{Abstract}

Alexandrium catenella (Whedon \& Kofoid) is a dinoflagellate known as a primary source of paralytic shellfish poisoning in Chile. The distribution range of harmful algal blooms generated by this species has extended during the last decades, and the frequency of these events has increased. In this work, we developed TaqMan markers from Chilean strains that can be used to identify and quantify through qPCR, which can be implemented in monitoring programs for the early detection of this species. 8 
Harmful Algal Blooms (HABs) are recurrent events along the Chilean coast, where

31 dinoflagellates species, such as Alexandrium catenella, Dinophysis acuminata,

Pseudochattonella verruculosa, and Karenia selliformis, are the culprit for most cases (Díaz et al., 2019; Lagos, 1998; Mardones et al., 2021, 2020). Blooms of Alexandrium catenella in Chile have extended their geographical distribution from Southern Patagonia $\left(53^{\circ} \mathrm{S}\right)$ to central Chile $\left(36^{\circ} \mathrm{S}\right)$ (Guzmán et al., 2002; Mardones et al., 2010), causing massive death of endemic fauna and economic losses to the aquaculture industries (Álvarez et al., 2019; Mardones et al., 2015; Mascareño et al., 2018; Montes et al., 2018). The potent saxitoxin and its derivatives produced by A. catenella (Anderson et al., 2012; Krock et al., 2007) can be accumulated in the filter-feeding bivalves at elevated concentrations (Navarro and Contreras, 2010; Pizarro et al., 2018), and humans who consumed the contaminated shellfish can be intoxicated and led to death (García et al., 2004). Implementing molecular tools into algal monitoring is one of the significant innovations because this technology, compared to traditional microscopic detection (Uthermöl, 1958), allows the target species detection with high taxonomic precision even at low concentrations (Anderson et al., 2019; Farrell et al., 2016; Galluzzi et al., 2005: Zhang et al., 2018).

Detection and quantification of molecular markers by quantitative PCR (qPCR) is one of the most attractive strategies for early warning of HAB species to mitigate the impacts of the events. Several prior studies introduced the molecular markers to identify Alexandrium species (Antonella \& Luca, 2013), convincing that this technique is highly valuable and potentially adaptable for the HAB monitoring systems (Hosoi-Tanabe and Sako, 2005; Kamikawa et al., 2007; Galluzzi et al., 2010; Gao et al., 2015; Garneau et al., 2011; Farrell et al., 2016; Murray et al., 2019; Vandersea et al., 2020). Chile has several on- 
going HAB monitoring programs (Sandoval et al., 2018; Yarimizu et al., 2020); however, none uses qPCR molecular markers to report the presence of A. catenella species. The government institution in charge of protecting public health in Chile considers the $A$. catenella species a hydrobiological plague. The molecular markers that can detect target species with high accuracy can support the current HAB monitoring programs. The purpose of our study was to develop TaqMan-based markers targeting ribosomal RNA genes of the Chilean A. catenella strains and to establish a PCR method utilizing these markers to quantify the in-vitro A. catenella.

In-vitro A. catenella cells (Chilean strain ACENM) and two negative controls, Pseudochattonella verruculosa (Hosoi-Tanabe et al., 2007) (Chilean strain CREAN_PV01) and Chattonella marina (Hara \& Chihara) (Japanese strain CM1), were maintained in sterile flasks $(70 \mathrm{ml})$ containing L1 media at $18 \square$ with 12-hr light cycle. These culture samples were filtered and processed for DNA extraction by the Chelex-buffer method (Nagai et al., 2012). The extracted gDNA was stable at $5 \square$ at least for three weeks. The primers and probe were designed from the conserved region by aligning 100 Chilean $A$. catenella sequences (28S rRNA gene) from GenBank, using MUSCLE (Edgar, 2004) implemented in Geneious (Biomatters Ltd): AC-1976F (GTG GGT GGT AAG TTT CAT GCA), AC-2245R (GTG CAA AGG TAA TCA AAT GTC CAC), and probe AC-2026P (FAM-CGC ACA AGT ACC ATG AGG GA-TAMRA). In-silico specificity was checked by Genious software and Primer-BLAST at the NCBI website. The qPCR standard was prepared as follows: The region between the primer set was amplified from the gDNA using KOD-plus-ver.2 (TOYOBO) with the thermal cycle initiation at $94^{\circ} \mathrm{C}$ for $2 \mathrm{~min}, 35$ cycles of denaturing at $94^{\circ} \mathrm{C}$ for $10 \mathrm{sec}$ and annealing at $58^{\circ} \mathrm{C}$ for $30 \mathrm{sec}$, and extension at 
$68^{\circ} \mathrm{C}$ for $40 \mathrm{sec}$. The product amplicon was verified for 249 bp by agarose gel and purified with a High Pure PCR Product Purification Kit (Roche). The purified amplicon was diluted with DNA/RNA free water to an 8-point standard ranging from 10 to $1 \times 10^{-6} \mathrm{ng} / \mu \mathrm{L}$. The SYBR qPCR was performed with an 8-point standard to ensure the melt-curve peak at $81 \square$, verifying the target gene amplification. SYBR method used $10 \mu 1$ sample mix containing 40 $\mathrm{nM}$ of each primer and $2 \times$ Lightcycler®480 SYBR Green I Master mix (Roche) with thermal cycle of initial enzyme activation at $95 \mathrm{C}$ for 15 min followed by 45 cycles of $95 \mathrm{C}$ for $10 \mathrm{sec}$ and $60 \mathrm{C}$ for $30 \mathrm{sec}$. Six different TaqMan master mix were evaluated by the 8point standard curve with triplicate samples by the qPCR program; initial incubation at 50 ${ }^{\circ} \mathrm{C}$ for $2 \mathrm{~min}$ and $95{ }^{\circ} \mathrm{C}$ for $10 \mathrm{~min}, 45$ cycles of $95{ }^{\circ} \mathrm{C}$ for $15 \mathrm{~s}$ and $60{ }^{\circ} \mathrm{C}$ for $1 \mathrm{~min}$. The tested master mix in $25 \mu \mathrm{L}$ consisted of $2.5 \mu \mathrm{L}$ of $10 \mu \mathrm{M}$ primers, and $1 \mu \mathrm{L}$ of $10 \mu \mathrm{M}$ probe, $2 \mu \mathrm{L}$ DNA, $12.5 \mu \mathrm{L}$ Kapa3G (KAPAbiosystems, KK7251), $0.3 \mu \mathrm{L}$ of 2.5U/ $\mu \mathrm{L}$ Kapa3 plant DNA poly $(2.5 \mathrm{U} / \mu \mathrm{L})$ with/out $3 \mu \mathrm{L}$ of $25 \mathrm{mM} \mathrm{MgCl}_{2}$, or the same primer and probe contents with $12.5 \mu \mathrm{L}$ TaqPath (Applied Biosystems, A30865) with/out $\mathrm{MgCl}_{2}$, or those with 12.5 $\mu \mathrm{L}$ Luna universal probe (BioLabs, M3004S) with/out 1.3 $\mu$ L Clarity JN solution (BioLabs, 12006). To test reproducibility, gDNA was extracted from the two different $A$. catenella culture flasks at two different dates (lot A and B), preparing a 5-point serial dilution from $10 \mathrm{ng} / \mu \mathrm{L}$ gDNA $(\mathrm{n}=2)$, which were analyzed by the TaqMan $\mathrm{qPCR}$. The specificity was verified by testing the gDNA $(0.1 \mathrm{ng} / \mu \mathrm{L})$ of $C$. marina and $P$. verruculosa with the TaqMan qPCR. Lastly, the method's capability to quantify $28 S$ rRNA gene (LSU) copies from gDNA was tested: A. catenella cell count of 30,000, 10,000, and 7,500 estimated by microscope were processed for DNA extraction and assayed by the TaqMan qPCR. The copy number of the target $28 S r R N A$ gene was determined by the 
equation, where DNA conc. is $\mathrm{SQ}$ value in $\mathrm{ng} / \mu \mathrm{L}, \mathrm{CF}$ is concentration factor, genome bp is $249 \mathrm{bp}$, the number of target gene is one based on the assumption of one target $28 \mathrm{~s} r \mathrm{RA}$ gene in the region between the primer set.

$$
\begin{aligned}
\text { gene copy } / \mathrm{L}= & \text { DNA conc. }\left(\frac{\mathrm{ng}}{\mu \mathrm{l}}\right) \times\left(\frac{1 \mathrm{~g}}{10^{9} \mathrm{ng}}\right) \times\left(\frac{1 \mathrm{~mol} \mathrm{bpDNA}}{660 \mathrm{~g} \text { DNA }}\right) \\
& \times\left(\frac{6.022 \times 10^{23} \mathrm{bp}}{\mathrm{mol} \mathrm{bp}}\right) \times\left(\frac{1 \text { copy }}{\text { genome bp }}\right) \times\left(\frac{\text { number of target gene }}{1 \text { genome of standard }}\right) \times \mathrm{CF}
\end{aligned}
$$

Of six TaqMan master mix evaluated, TaqPath, Luna with JN solution, and Kapa3G with $\mathrm{MgCl}_{2}$ provided the best and comparable standard curves. The results obtained with Kapa3G are shown hereafter. The 8-point standard curve showed $\mathrm{R}^{2}=0.997$ and efficiency of $102.9 \%$ (Figure 1A, 1B). The standard curve was converted to gene copies (Figure 1C). The reproducibility was confirmed by the comparable TaqMan qPCR results obtained from the two lots of gDNA (Figure 2A, 2B). This result indicated that the method was able to quantify the target gene from the culture gDNA within the range of $10-10^{-2} \mathrm{ng} / \mu \mathrm{L}$ ( $\mathrm{R}^{2} \geqq 0.99$ for both lots). The gDNA at $10^{-3} \mathrm{ng} / \mu \mathrm{L}$ was below the detection limit of the method. The method specificity for A. catenella was confirmed as there was no detection of $C$. marina, and the signal from $P$. verruculosa was below the limit of quantitation (Figure 2C, 2D), and the melt peak from these species did not match with that from $A$. catenella $\left(81^{\circ} \mathrm{C}\right)$. The target gene copy was average 37,422 per cell, obtained from the $A$. catenella cell count of 30,000, 10,000, and 7,500 assayed by the TaqMan-qPCR. The starting cell count lower than 1,000 showed considerable variability in the resulting copy numbers per cell. When gDNA was extracted from 10,000 cells first and diluted by 10-fold, equivalent to the gDNA quantity from 1,000 cells, the obtained copies per cell were comparable to the average described above. Thus, the cell ratio to a volume at the starting point must be adjusted for the method to obtain reproducible gene copies. 
121 established a TaqMan-qPCR method to identify and quantify the species in the cultures.

122 The highlight of this work is that the markers were designed from 100 sequences obtained

123 from Chilean Alexandrium catenella strains, aiming to capture the genetic diversity of this

124 species in Chilean coastal monitoring. This is the first marker development targeting the

125 detection of Chilean A. catenella strains and has a great potential to serve for early warning

126 tool for Chilean A. catenella. The main difference with the work of Murray et al. (2018) is

127 that our makers contain a probe to the qPCR method to increase the specificity, as other

128 Alexandrium species have similar sequences. Our preliminary environment sample testing

129 with these makers indicated that the method is quantitative; however, we should keep in

130 mind that the copy number of ribosomal genes is highly variable in Alexandrium species

131 (Galluzzi et al., 2010), when the method is applied to environment samples. Overall, the

132 method has a broader potential for field sample surveys to mitigate the HAB impacts. The

133 fisheries equipment transport, ballast water of ships, and the projections under climate

134 change can transport microalgae to spread to broader geographic areas (Griffith and Gobler,

135 2020; Rodríguez-Villegas et al., 2020), introducing the HABs with new species and further

136 leading to recurrence of the events. The addition of the molecular techniques to the current

137 Chilean $\mathrm{HAB}$ monitoring programs can provide comprehensive information and strengthen

138 our knowledge of the phytoplankton dynamics in the regional waters. The method is highly

139 beneficial for early warning of the target HAB species with cell densities, informing the

140 relevant authorities, which can reduce the public health, ecological and economic impacts

141 (Hernandez-Becerril et al., 2018). 
Acknowledgements: This study was supported by the Instituto de Fomento Pesquero (IFOP) (Grants MR656-114, MR656-123) and the grant (JPMJSA1705) for a study on Science and Technology Research Partnership for Sustainable Development - Monitoring Algae in Chile (SATREPS-MACH).

\section{References}

Álvarez, G., Díaz, P.A., Godoy, M., Araya, M., Ganuza, I., Pino, R., Álvarez, F., Rengel, J., Hernández, C., Uribe, E., Blanco, J., 2019. Paralytic shellfish toxins in surf clams Mesodesma donacium during a large bloom of Alexandrium catenella dinoflagellates associated to an intense shellfish mass mortality. Toxins (Basel). 11. https://doi.org/10.3390/toxins11040188

Anderson, C.R., Berdalet, E., Kudela, R.M., Cusack, C.K., Silke, J., O’Rourke, E., Dugan, D., McCammon, M., Newton, J.A., Moore, S.K., Paige, K., Ruberg, S., Morrison, J.R., Kirkpatrick, B., Hubbard, K., Morell, J., 2019. Scaling Up From Regional Case Studies to a Global Harmful Algal Bloom Observing System. Front. Mar. Sci. 6. https://doi.org/10.3389/fmars.2019.00250

Anderson, D.M., Alpermann, T.J., Cembella, A.D., Collos, Y., Masseret, E., Montresor, M., 2012. The globally distributed genus Alexandrium: Multifaceted roles in marine ecosystems and impacts on human health. Harmful Algae 14, 10-35. https://doi.org/10.1016/j.hal.2011.10.012

Antonella, P., Luca, G., 2013. The quantitative real-time PCR applications in the monitoring of marine harmful algal bloom (HAB) species. Environ. Sci. Pollut. Res. 20, 6851-6862. https://doi.org/10.1007/s11356-012-1377-z 
165

166

167

168

169

170

171

172

173

174

175

176

177

178

179

180

181

182

183

184

185

186

187

Díaz, P.A., Álvarez, G., Varela, D., Pérez-Santos, I., Díaz, M., Molinet, C., Seguel, M., Aguilera-Belmonte, A., Guzmán, L., Uribe, E., Rengel, J., Hernández, C., Segura, C., Figueroa, R.I., 2019. Impacts of harmful algal blooms on the aquaculture industry: Chile as a case study. Perspect. Phycol. 6, 39-50. https://doi.org/10.1127/pip/2019/0081

Farrell, H., O'Connor, W., Seebacher, F., Harwood, D.T., Murray, S., 2016. Molecular Detection of the Sxta Gene from Saxitoxin-Producing Alexandrium minutum in $\begin{array}{llllll}\text { Commercial } & \text { Oysters. } & \text { J. } & \text { Shellfish } & \text { Res. } & 35,\end{array}$ https://doi.org/10.2983/035.035.0118

Galluzzi, L., Bertozzini, E., Penna, A., Perini, F., Garcés, E., Magnani, M., 2010. Analysis of rRNA gene content in the Mediterranean dinoflagellate Alexandrium catenella and Alexandrium taylori: Implications for the quantitative real-time PCR-based monitoring methods. J. Appl. Phycol. 22, 1-9. https://doi.org/10.1007/s10811-009$9411-3$

Galluzzi, L., Penna, A., Bertozzini, E., Giacobbe, M.G., Vila, M., Garcés, E., Prioli, S., Magnani, M., 2005. Development of a qualitative PCR method for the Alexandrium spp. (Dinophyceae) detection in contaminated mussels (Mytilus galloprovincialis). Harmful Algae 4, 973-983. https://doi.org/10.1016/j.hal.2005.01.004

Gao, Y., Yu, R.C., Murray, S.A., Chen, J.H., Kang, Z.J., Zhang, Q.C., Kong, F.Z., Zhou, M.J., 2015. High specificity of a quantitative PCR assay targeting a saxitoxin gene for monitoring toxic algae associated with paralytic shellfish toxins in the Yellow Sea. Appl. Environ. Microbiol. 81, 6973-6981. https://doi.org/10.1128/AEM.00417-15 
García, C., Bravo, M.D.C., Lagos, M., Lagos, N., 2004. Paralytic shellfish poisoning: Postmortem analysis of tissue and body fluid samples from human victims in the Patagonia fjords. Toxicon 43, 149-158. https://doi.org/10.1016/j.toxicon.2003.11.018

Garneau, M.È., Schnetzer, A., Countway, P.D., Jones, A.C., Seubert, E.L., Caron, D.A., 2011. Examination of the seasonal dynamics of the toxic dinoflagellate Alexandrium catenella at Redondo Beach, California, by quantitative PCR. Appl. Environ. Microbiol. 77, 7669-7680. https://doi.org/10.1128/AEM.06174-11

Hosoi-Tanabe, S., Sako, Y., 2005. Species-specific detection and quantification of toxic marine dinoflagellates Alexandrium tamarense and A. catenella by real-time PCR assay. Mar. Biotechnol. 7, 506-514. https://doi.org/10.1007/s10126-004-4128-4

Hosoi-Tanabe, S., Honda, D., Fukaya, S., Otake, I., Inagaki, Y., \& Sako, Y. (2007). Proposal of Pseudochattonella verruculosa gen. nov., comb. nov. (Dictyochophyceae) for a formar raphidophycean alga Chattonella verruculosa, based on 18S rDNA phylogeny and ultrastructural characteristics. Phycological Research, 55, 185-192. doi:10.1111/j.1440-1835.2007.00461.x

Kamikawa, R., Nagai, S., Hosoi-Tanabe, S., Itakura, S., Yamaguchi, M., Uchida, Y., Baba, T., Sako, Y., 2007. Application of real-time PCR assay for detection and quantification of Alexandrium tamarense and Alexandrium catenella cysts from marine sediments. Harmful Algae $6, \quad 413-420$. https://doi.org/10.1016/j.hal.2006.12.004

Krock, B., Seguel, C.G., Cembella, A.D., 2007. Toxin profile of Alexandrium catenella from the Chilean coast as determined by liquid chromatography with fluorescence detection and liquid chromatography coupled with tandem mass spectrometry. 
Lagos, N., 1998. Microalgal blooms: A global issue with negative impact in Chile. Biol. Res. 31, 375-386.

Mardones, J., Clément, A., Rojas, X., Aparicio, C., 2010. Alexandrium catenella during 2009 in Chilean waters, and recent expansion to coastal ocean. Harmful Algae News $41,8-9$.

Mardones, J.I., Dorantes-Aranda, J.J., Nichols, P.D., Hallegraeff, G.M., 2015. Fish gill damage by the dinoflagellate Alexandrium catenella from Chilean fjords: Synergistic action of ROS and PUFA. Harmful Algae 49, 40-49. https://doi.org/10.1016/j.hal.2015.09.001

Mardones, J.I., Norambuena, L., Paredes, J., Fuenzalida, G., Dorantes-Aranda, J.J., Chang, K.J.L., Guzmán, L., Krock, B., Hallegraeff, G., 2020. Unraveling the Karenia selliformis complex with the description of a non-gymnodimine producing Patagonian phylotype. Harmful Algae 98. https://doi.org/10.1016/j.hal.2020.101892

Mardones, J.I., Paredes, J., Godoy, M., Suarez, R., Norambuena, L., Vargas, V., Fuenzalida, G., Pinilla, E., Artal, O., Rojas, X., Dorantes-Aranda, J.J., Lee Chang, K.J., Anderson, D.M., Hallegraeff, G.M., 2021. Disentangling the environmental processes responsible for the world's largest farmed fish-killing harmful algal bloom: $\begin{array}{lllll}\text { Chile, } & \text { 2016. } & \text { Sci. } & \text { Total } & \text { Environ. }\end{array}$ https://doi.org/10.1016/j.scitotenv.2020.144383

Mascareño, A., Cordero, R., Azócar, G., Billi, M., Henríquez, P.A., Ruz, G.A., 2018. Controversies in social-ecological systems: Lessons from a major red tide crisis on Chiloe island, Chile. Ecol. Soc. 23. https://doi.org/10.5751/ES-10300-230415 
Montes, R.M., Rojas, X., Artacho, P., Tello, A., Quiñones, R.A., 2018. Quantifying harmful algal bloom thresholds for farmed salmon in southern Chile. Harmful Algae 77, 55-65. https://doi.org/10.1016/j.hal.2018.05.004

Murray, S.A., Ruvindy, R., Kohli, G.S., Anderson, D.M., Brosnahan, M.L., 2019. Evaluation of sxtA and rDNA qPCR assays through monitoring of an inshore bloom of Alexandrium catenella Group 1. Sci. Rep. 9, 1-12. https://doi.org/10.1038/s41598$019-51074-3$

Navarro, J.M., Contreras, A.M., 2010. An integrative response by Mytilus chilensis to the toxic dinoflagellate Alexandrium catenella. Mar. Biol. 157, 1967-1974. https://doi.org/10.1007/s00227-010-1465-x

Pizarro, G., Paz, B., Alarcón, C., Toro, C., Frangópulos, M., Salgado, P., Olave, C., Zamora, C., Pacheco, H., Guzmán, L., 2018. Winter distribution of toxic, potentially toxic phytoplankton, and shellfish toxins in fjords and channels of the Aysén region, Chile. Lat. Am. J. Aquat. Res. 46, 120-139. https://doi.org/10.3856/vol46-issue1fulltext-13

Sandoval, M., Parada, C., Torres, R., 2018. Proposal of an integrated system for forecasting harmful algal blooms (HAB) in Chile. Lat. Am. J. Aquat. Res. 46, 424-451. https://doi.org/10.3856/vol46-issue2-fulltext-18

Vandersea, M.W., Kibler, S.R., Sant, S.B. Van, Tester, P.A., Eckert, G., Cammarata, C., Reece, K., Scott, G., Place, A., Holderied, K., Hondolero, D., Litaker, R.W., Noaa, N., 2020. species-specific Alexandrium molecular assays 56, 303-320. https://doi.org/10.2216/16-41.1.qPCR

Yarimizu, K., Fujiyoshi, S., Kawai, M., Norambuena-Subiabre, L., Cascales, E. K., Rilling, 
J. I., Vilugrón, J., Cameron, H., Vergara, K., Morón-López, J., Acuña, J. J., Gajardo,

258 G., Espinoza-González, O., Guzmán, L., Jorquera, M. A., Nagai, S., Pizarro, G.,

259 Riquelme, C., Ueki, S., Maruyama, F. (2020). Protocols for Monitoring Harmful Algal

260 Blooms for Sustainable Aquaculture and Coastal Fisheries in Chile. Int. J. Environ.

261 Res. Public Health, 17(20). doi:10.3390/ijerph17207642

262 Zhang, C., Chen, G., Wang, Y., Sun, R., Nie, X., \& Zhou, J. (2018). MHBMDAA:

263 Membrane-based DNA array with high resolution and sensitivity for toxic

264 microalgae monitoring. Harmful Algae, $\quad 80, \quad$ 107-116.

265 doi:https://doi.org/10.1016/j.hal.2018.10.004

266 

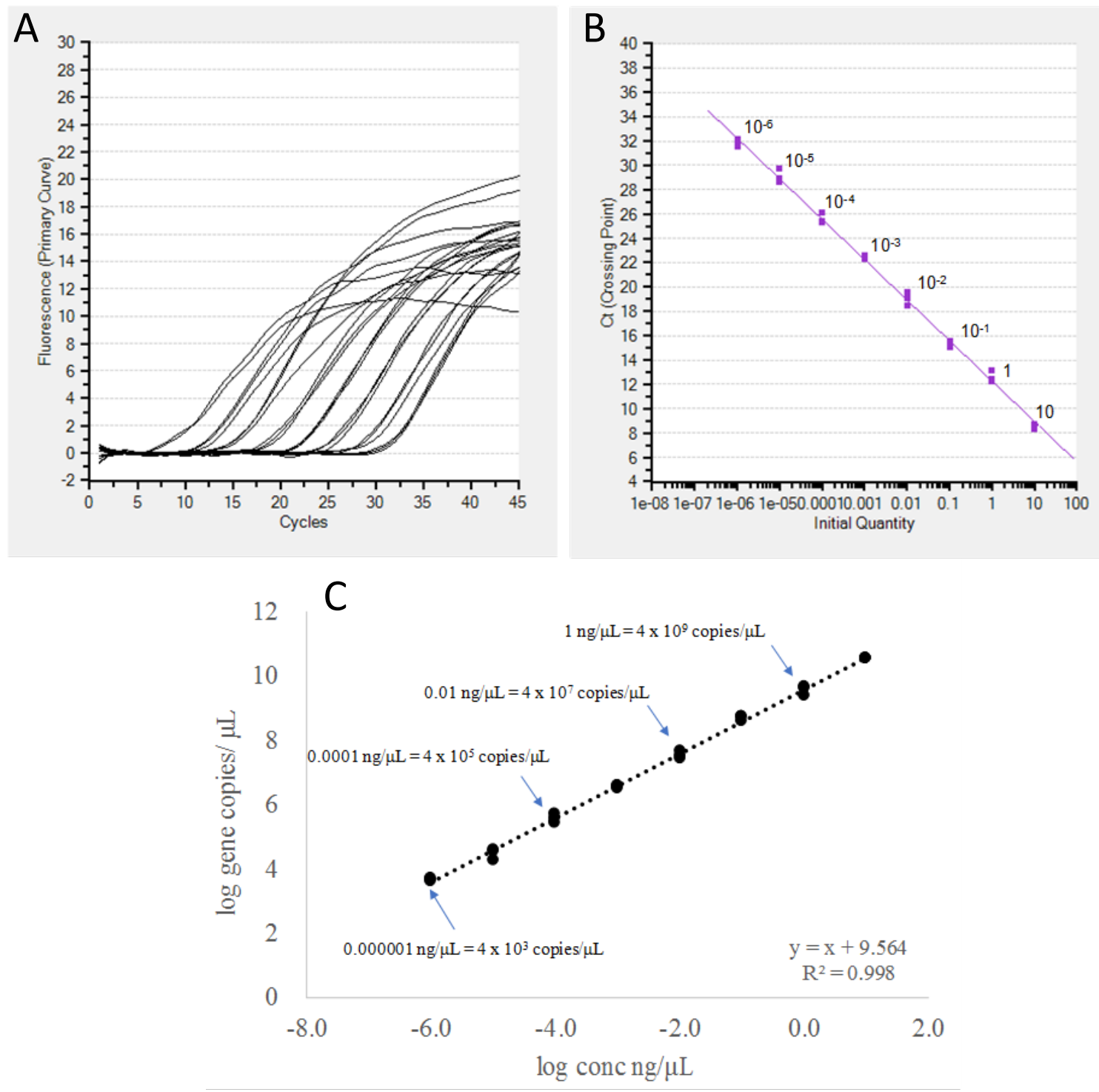

Figure 1. Standard curve of culture-based DNA treated by PCR with the primer AC-1976F and AC-2245R, for the eight-point serial dilution made from $10 \mathrm{ng} / \mu \mathrm{L}$ of standard $(\mathrm{n}=3)(\mathrm{A}$ and B). Conversion of from concentration to gene copies by calculation based on the assumption that there is one 28s rRNA target gene in the region between primer AC-1976F and AC-2245R (n=3) (C). 

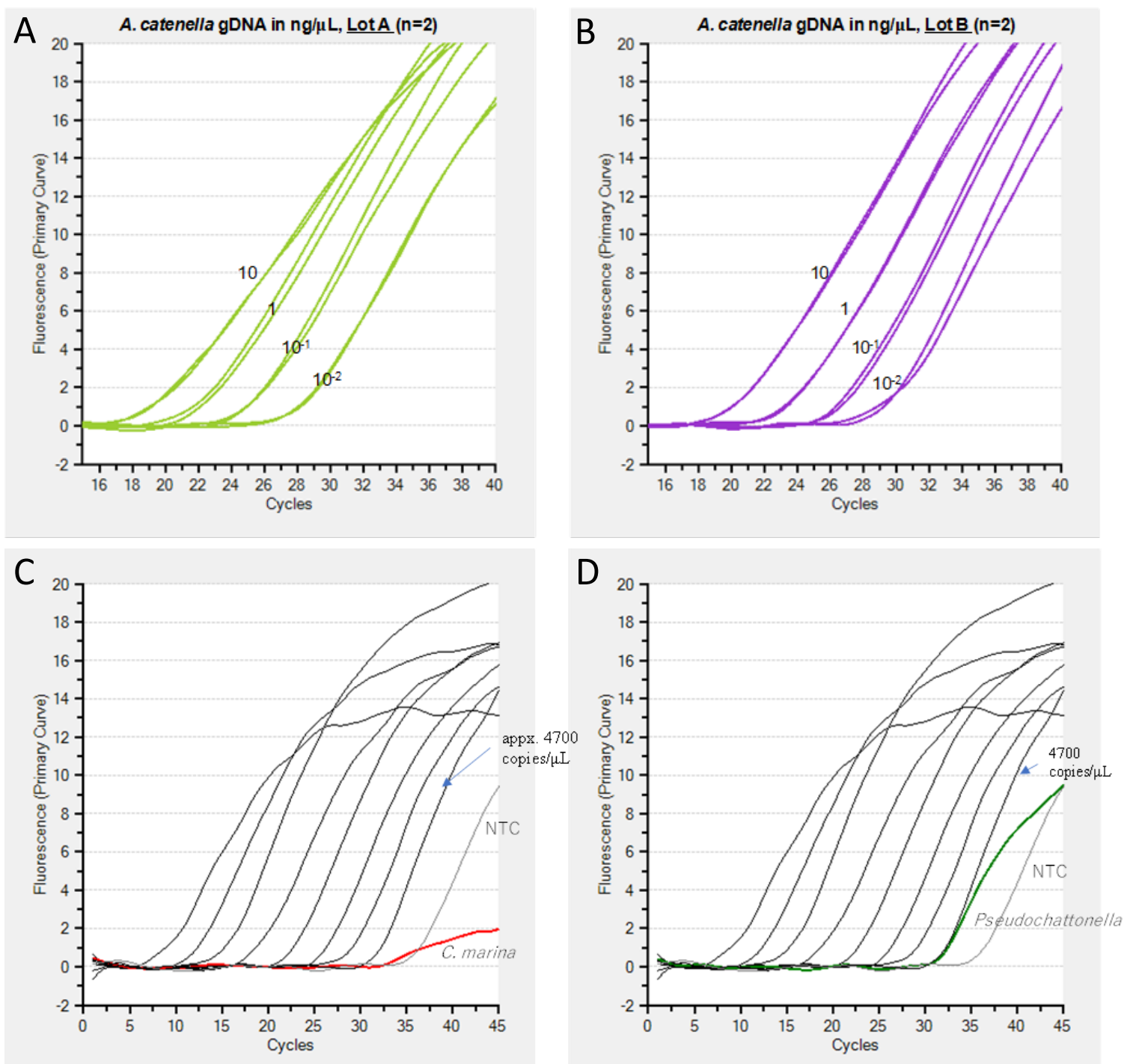

Figure 2. DNA of $A$. catenella from the two different culture flasks tested by the Taq-Man qPCR with Kapa3 master mix. The 5-point serial dilution was made for each DNA based on the $10 \mathrm{ng} / \mu \mathrm{L}$ of DNA concentration as the stock and the gDNA above $10^{-2} \mathrm{ng} / \mu \mathrm{L}$ was detected with the linear regression above $0.99(\mathrm{n}=2)(\mathrm{A}$ and $\mathrm{B})$. The gDNA extracted from C. marina and Pseudochattonella were tested with the A. catenella TaqMan-qPCR. There was no detection of $C$. marina. The signal obtained from the $P$. verruculosa was below the lowest standard concentration (C and D). 